\title{
Indigenous teachers' experiences of the implementation of culture-based mathematics activities in Sámi school
}

\author{
Ylva Jannok Nutti
}

Received: 10 September 2012 / Revised: 14 January 2013 / Accepted: 16 January 2013 /

Published online: 3 February 2013

(C) Mathematics Education Research Group of Australasia, Inc. 2013

\begin{abstract}
The goal of Indigenous education is that it should be approached on the basis of the Indigenous language and culture; this is also the case with Sami education. The Sámi School Board has stated that all teaching in Sámi schools should be culturally based, despite the fact that Sámi culture-based teaching is not specifically defined. Therefore, teachers themselves must adapt the teaching and as a result, usually no Sámi culture-based mathematics teaching takes place. The aim of this article is to discuss Indigenous teachers' experiences with designing and implementing culture-based mathematics activities in Sámi preschool and primary school. The teachers' work with culture-based mathematics activities took the form of Sámi cultural thematic work with ethnomathematical content, Multicultural school mathematics with Sámi cultural elements, and Sámi intercultural mathematics teaching. Culture-based mathematics activities took place within an action research study in the Swedish part of Sápmi. Sápmi comprises northern Norway, Sweden, and Finland, as well as the Kola Peninsula in Russia. In the action research study, six teachers conducted culture-based mathematics activities in preschool and primary school on the basis of the action research loop "plan-act-observe-reflect." During the study the teachers changed from a problem-focused perspective to a possibility-focused culture-based teaching perspective characterised by a self-empowered Indigenous teacher role, as a result of which they started to act as agents for Indigenous school change. The concept of "decolonisation" was visible in the teachers' narratives. The teachers' newly developed knowledge about the ethnomathematical research field seemed to enhance their work with Indigenous culture-based mathematics teaching.
\end{abstract}

Keywords Sámi and Indigenous education · Sámi and Indigenous teachers · Culturallybased mathematics teaching - Action research · Ethnomathematics · Self-empowerment and decolonisation

\footnotetext{
Y. J. Nutti $(\bowtie)$

Department of Education, University of Tromsø, 9037 Tromsø, Norway

e-mail: ylva.jannok.nutti@uit.no
} 


\section{Introduction}

This article discusses Sámi teachers' experiences of Indigenous school transformation and their work with transforming teaching and teaching content into Sámi culturebased mathematics activities with reference to an action research study by Nutti (2010) and a result that was further discussed by Nutti (2012).

The Indigenous Sámi people inhabit an area called Sápmi. Sápmi comprise the coastal and inland regions of northern Norway, Sweden, and Finland, as well as the Kola Peninsula in Russia. The Sámi people have their own languages and each language includes a number of dialects. The education of Sámi children differs from country to country and this article mainly focuses on Sámi education for Sámi children living in the Swedish part of Sápmi. There Sámi teachers worked together with children at preschool and pupils at primary school to transform the teaching and teaching content into Sámi culture-based activities. This transformation work was conducted within the action research study (Nutti 2010) at Luleå University of Technology in co-operation with the Sámi School Board, which is responsible for managing Sámi education in Sámi schools in the Swedish part of Sápmi.

Sámi schools comprise primary school years 1-6, preschool, and leisure centre activities. At present, there are five Sámi schools in Sweden. Sámi education at Sámi schools in Sweden is equal to Swedish national education, but the Sámi schools should also convey norms, values, and traditions of the Sámi society and also the Sámi cultural heritage to Sámi pupils (Skolverket 2011). To pass on the Sámi norms, values, traditions, and cultural heritage the Sámi School Board (Sameskolstyrelsen 2007) announced that all teaching in Sámi schools should be based on Sámi culture. In addition, teaching in Sámi language must take place, and the Sámi schools are therefore governed by the Sámi language curriculum. The Sámi curriculum states that pupils should be given the opportunity to develop knowledge of Sámi society, history, livelihoods, and traditions (Skolverket 2011). The opportunity to develop knowledge about Sámi society, history, livelihoods, and traditions could indicate that the Sámi language curriculum is intended to be implemented also in other subjects. However, there are no specially authorised curricula for other subjects in Sámi schools in Sweden. It is therefore up to each teacher to design and develop a culture-based Sámi education by transforming cultural knowledge into teaching, with the result that no cultural implementation usually takes place in mathematics.

In the action research study (Nutti 2010), Sámi teachers transformed Sámi cultural knowledge into culture-based mathematics activities. The aim of the present article is to discuss Indigenous teachers' experiences of implementing Sámi culture-based activities. What possibilities and challenges do the teachers describe concerning Sámi culture-based mathematics teaching? What kind of Sámi culture-based activities did the teachers design and in what way did the teachers transform Sámi culturebased activities into teaching?

\section{Decolonisation of indigenous education}

In previous decades, schools for Indigenous, including Sámi children, were often boarding schools. There the children were taught western values and ways of life and 
in a sense prevented from gaining cultural knowledge (Kuokkanen 2000). The development of culture-based teaching and teaching content can be a way of "... reclaiming, reformulating and reconstituting Indigenous cultures and languages..." (Smith 2004, p. 142). Therefore Indigenous peoples need to restore: “...Indigenous ecologies, consciousness, and languages by creating bridges between Indigenous and Eurocentric knowledge" (Battiste 2000: xvii). Indigenous researchers such as Laenui (2000) discussed this restoration by using the concept of decolonisation. Decolonisation consists, according to Laenui (2000), of: “...(1) rediscovery and recovery, (2) mourning, (3) dreaming, (4) commitment and (5) action" (2000, p. 152).

Smith (2000) criticised actions based on colonisation and suggested that Indigenous peoples should instead focus on pro-active initiatives. Teachers' proactive initiatives and responsibility to act to achieve school change were analysed by Bedford (2009). In his action research study, the concepts of "power" and "empowerment" were identified as tools for the realisation of change. The concept of power was defined as: "The drive, ability and possibility of an individual or group to act" (Bedford 2009, p. 55) and the concept of empowerment as: "A process that increases the drive, ability and possibility of an individual group to act" (Bedford 2009, p. 55). Bedford (2009) revealed that the teachers in his study expressed a willingness to promote school change, but they did not always act on account of various personal, cultural, and structural barriers. However, during the study Bedford observed an empowered and changed teacher role, where teachers became empowered and started acting as agents for school change. The concept of empowerment has been questioned by Kuokkanen (2007), because it can mean giving another person influence. According to Kuokkanen, this is incorrect because no one can increase another person's capacity, a fact earlier stressed by Townsend et al. (1999), who instead used the concept of self-empowerment.

\section{Multi- or intercultural education}

Hirvonen (2004) used Banks's (2004) multicultural education model to examine the Sámi curriculum and its implementation. Banks's model has four approaches that investigate the integration of multicultural content in teaching. The first is the contributions approach, where multiculturalism is seen as a supplement to the education and the focus is on heroes, holidays, and discrete cultural elements. In this approach Hirvonen placed the teaching in many Sámi schools outside the Sámi majority speaking areas. The second is the additive approach, where multicultural content, concepts, and themes are added to the curriculum without changing its structure. Hirvonen used this approach to describe Sámi schools in the Sámi majority speaking area of Norway, where the national content is merely translated into Sámi. The third is the transformation approach, where the structure of the curriculum is changed to enable pupils to view concepts, issues, events, and themes from the perspective of diverse cultural groups. This approach would be used in a culturebased Sámi School. The fourth is the social action approach, which includes elements of all the other approaches combined with teaching that encourages pupils to become actively involved in social and political affairs, thus enabling young people from 
different cultural and social groups to experience equality of education (Banks 2004). The separate Sámi curriculum is a step in the right direction towards a Sámi culturebased or multicultural education, although Hirvonen (2004) emphasised in the evaluation study that the Sámi School has not yet been fully achieved. Hirvonen's (2004) conclusion was that until it is possible to deem Sámi schools multicultural, they should be based on Sámi ontology and epistemology.

Banks (2004) and Hirvonen (2004) used the term "multicultural education," but, today, this term is often replaced by "intercultural education." The concept of multicultural education can be interpreted as an education that encompasses the traditions and knowledge of different cultural groups, while the concept of "intercultural education" can be understood as a way of allowing different cultural groups to meet, communicate, and learn from each other's traditions and knowledge. Intercultural education is thus a way of encountering a multicultural society with the ambition of transforming it on the basis of different cultures (Lahdenperä 2008). Both the concepts, "multicultural" and "intercultural," can be included in Banks's multicultural model. Multicultural education has been discussed for over 20 years in mathematics teaching, including the field of ethnomathematics.

\section{Ethnomathematics}

The term "ethnomathematics" was introduced by D'Ambrosio (1985), and Ascher's (1991) definition was: "the study and presentation of mathematical ideas of traditional peoples" (1991:188). Traditional mathematics or mathematics as a cultural knowledge according to Bishop (1988) is developed on the basis of six universal activities: counting, locating, measuring, designing, playing, and explaining. More specifically, counting and knowledge of counting; locating and how to encode and navigate the natural environment; measuring and how to measure including measurement units and methods; designing and how to design items, artifacts, and technology; playing and how to play including games and activities; and searching for and explaining a theory or connecting pattern (Bishop 1988, 1991).

The ethnomathematical research can enable a reconstruction of Indigenous mathematical knowledge such as ideas, concepts, and principles (Barton 1999). And according to D'Ambrosio (2006) the ethnomathematical research field has clear implications for teaching, but Vithal and Skovsmose (1997) and Pais (2011) brought forward a critique of D'Ambrosio and the ethnomathematical research field. Pais (2011) criticised ethnomathematics both according to both epistemological and pedagogical issues. He argued for deeper theoretical discussions within the ethnomathematical research field, so that well-intended school actions do not have a result opposite to their aims.

\section{Earlier studies related to Sámi culture-based mathematics teaching}

In an earlier evaluation study Skolverket (2002) asked Swedish Sámi schools: 'Is there, or has there been, any special mathematics in the Sámi culture? And in what contexts are mathematics used in the Sámi culture" (translated from Skolverket 2002, 
p. 15). These questions served as the starting point for a study by Nutti (2007), in which Sámi handicrafters' and reindeer herders' stories were analysed in relation to Bishop's (1988) six activities. The result (Nutti 2007) showed that there are several conceptions, for example different names for reindeer herds based on the approximate number of animals. Unusual reindeer, for example animals with a distinctive colours, function as support in counting or approximation of the wholeness of the herd. This is because reindeer herders easily recognise and identify this reindeer and if some of them are missing the herd is incomplete. The number of branded reindeer calves was counted by making marks on a wooden stick, by saving part of the ears of the branded calves, or by making notes on a piece of paper. Locating was made possible by wellknown objects in the natural environment, by the wind, or by rivers. The cardinal points were based on the landscape, the rivers, or lakes and the valleys around them. Body measurements were used. Depth of snow and water was measured with a stick or a rope and body measurement units, or with the help of the complete body. Distance was measured by the time it took to walk, by sound, or by sight. The concept of beanagullan is an example of a unit of measurement of distance. Beanagullan can be translated as the distance at which a dog's bark can be heard. Eight seasons divided the year and time was regulated by heat, light, or seasonal activities. The designing activity involves designing of buildings and artefacts.

Traditional knowledge involves practical and theoretical understanding of the use of the natural environment (Bergstrøm 2001). Stories, instructions, and explanations were essential parts of traditional learning, which took place during traditional activities. The key to Sámi up-bringing was for children to become iešbirgejeaddji, independent, and to birget, manage (Balto 1997). The concept "birget" implies managing to survive and becoming financially self-sufficient, which requires a need for knowledge and skills that enable independence.

It is possible to change teaching by transforming Indigenous knowledge into a culture-based mathematics curriculum and culture-based mathematics lessons (Lipka et al. 1998, 2005). Familiar and recurrent practices that occur outside of school can be reconstructed as a task in a mathematical textbook. However, recalling everyday experiences can constitute dilemmas. Meaney (2001) revealed a tension between teachers' and parents' desires, on the one hand, that Indigenous pupils should grow up with a strong cultural identity and, on the other, that they should be successful at school and later have the possibility to obtain well-paid jobs. The same tension has also been visible in other studies (Balto 2008; Johansson 2009). Another dilemma could be that some students make too extensive references to cultural and everyday knowledge when solving mathematical word problems in the textbook (Gellert and Jablonka 2009). On the other hand, several studies (for example Lipka and Adams 2004) show that pupils can do well in mathematics if given opportunities to integrate their everyday activities into mathematics learning in schools.

The Norwegian part of Sápmi already has a separate Sámi curriculum, but in terms of mathematics education it is more or less an adaptation of the Norwegian curriculum (Hirvonen 2004; Pettersen 2006; Fyhn 2010). And as Lauhamaa (2004) pointed out, Sámi schools are still mainly organised by the teachers on the basis of textbooks. This is consistent with the previous mentioned evaluation study, where mathematics teaching was described as textbook driven (Skolverket 2002). The study stressed: "Mathematics is for both students and teachers simply what is in the textbook" 
(translated from Skolverket 2002, p. 28). In the Sámi majority speaking areas in Norway, mathematics usually means the use of textbooks translated from Norwegian into Sámi languages. Translations have both positive and negative aspects (Utsi 2004). The positive aspect is that the Sámi language is used for learning mathematics. On the other hand, a negative aspect may be that the translations are not based on Sámi values (Utsi 2004; Pettersen 2006).

Still the Sámi languages are used in mathematics classrooms (at least in the Norwegian part of Sápmi) and the language might be used in different ways; for example mathematics teaching can occur on Sámi supported by Norwegian mathematics terms, or mathematics teaching is in Sámi with Sámi mathematics terms (Fyhn et al. 2011). Ellen, a teacher (in Fyhn et al. 2011), believes that pupils will benefit from knowing the Norwegian as well as the Sámi terms and there is an ongoing discussion regarding which terms are the best to use in school (Fyhn et al. 2011). Developing an Indigenous mathematics terminology is a challenging proposition, if it tries to both support students' learning of mathematics through transparency of meanings and keep the language strong (Meaney et al. 2012).

\section{Method, data, and analysis}

The aim of this article is to discuss teachers' experiences of Sámi culture-based mathematics activities. What possibilities and challenges do the teachers describe concerning Sámi culture-based mathematics teaching? What kind of Sámi culturebased activities did the teachers design and in what way did the teachers transform Sámi culture-based activities into teaching in preschool and primary school? The research material was collected during the action research study by Nutti (2010) from 2007 to 2010 . The research material comprises individual and group interviews with teachers. At the start of the study group interviews were conducted with teachers at four Sámi schools and the interviews were based on questions regarding problems and possibilities for culture-based teaching/mathematics teaching. The research material also comprises interviews with six teachers at two Sámi schools; four primary school teachers, one preschool teacher, and one leisure centre teacher. The interviews with the six teachers were conducted around their work with culture-based activities in Sámi schools. The activities were carried out in a preschool group with children of aged 5 years, five primary school classes with pupils aged 6 to 12 years, and a leisure centre group with children aged 6 to 10 years. The interviews were conducted in the beginning, during and at the end of the study.

The culture-based activities were conducted on the basis of the action research loop "plan-act-observe-reflect" (Kemmis and McTaggart 1988). The activities were documented by photos, video recordings, and a research diary, as well as the teachers' own texts and notes. The activities were reflected on during the interviews by means of the stimulated recall method (Calderhead 1996), which can be used to help someone recall their own thoughts and comment on their own work (Alexandersson 1994). Stimulated recall was intended to give the teachers opportunities to reflect on the activities in their own words and from their own perspectives. These interviews were documented by sound recording via a Dictaphone and log notes. 
The research process was cyclic, including the analysis of the course of action, as is usual in an action research study (Kemmis and McTaggart 1988). Teachers' reflections during interviews emanated from the directly experienced situation in the preschool group, the classes at the primary schools, and the leisure centre group, and aimed to contribute to future activities (Rönnerman 2000). Knowledge was exchanged between teachers and researcher during the action research study, during interviews, and during the three seminars that were part of the action research study. During the seminars teachers were able to take part in lectures and workshops around such topics as culture-based mathematics teaching, ethnomathematics, and Sámi traditional knowledge. The first seminar was attended by teachers from two schools, the second by teachers from three schools, and the third by preschool teachers, primary teachers, and leisure centre teachers from all five Sámi schools. The research material has been constructed through cooperative social interaction and therefore the knowledge was created in collaboration with the teachers and assessed by the researcher. The research material was divided into meaningful components, while maintaining the connection to the whole material (Ödman 2007); the analysis was data driven.

\section{Sámi culture-based activities}

Teachers designed and implemented culture-based activities and provided examples of how mathematics teaching can be linked to everyday life outside school and integrated into specific Sámi contexts. The Sámi culture-based mathematics activities that teachers designed and implemented in preschools and schools comprised grouse hunting, reindeer herding, handicraft, fishing, sporting events, cooking, baking, and so on. The lessons were interpreted with the help of Banks's (2004) multicultural model. The term "multicultural" refers to Sámi culture and national western school mathematics. Banks's model has been extended by the term "intercultural" on the basis of Lahdenperä's (2008) definition of the transfer of traditions and knowledge between different cultural groups. Sámi culture-based activities using Banks's (2004) model comprised:

1. Sámi cultural thematic work with ethnomathematical content.

2. Multicultural school mathematics with Sámi cultural elements.

3. Sámi intercultural mathematics teaching.

4. Sámi intercultural education based on Sámi ontology and epistemology (Nutti 2012).

The first two approaches concern culture-based mathematics activities where the multicultural mathematics teaching was carried out with the addition or contribution of Sami cultural content. In these two approaches there was no intercultural intention that the multicultural content, that is, the Sámi cultural theme and school mathematics, should interact with each other, which Lahdenperä (2008) stated is the difference between the multicultural and intercultural perspective. The third approach was intercultural and the intention of the culture-based mathematics activities was to reconstruct school mathematics by creating a learning environment grounded in both school mathematics and Sámi culture-based knowledge. The fourth approach 
concerns intercultural education, where teaching is changed on the basis of Sámi ontology and epistemology.

Sámi cultural thematic work with ethnomathematical content

Some of the culture-based mathematics activities can be described as Sámi cultural thematic work with ethnomathematical content. The culture-based themes included reindeer herding, grouse hunting, and measuring the snow depth. The theme work contained ethnomathematical elements based on Bishop's (1988) activities: counting and measuring. The earlier study including Sámi handicraft and reindeer herding (Nutti 2007) was used as a background for teachers' work with Sámi culture-based activities. Ethnomathematical or traditional mathematical elements were a part of the cultural theme, but the activities lacked focus on mathematical knowledge. During activities involving reindeer herding, reindeer were counted. Pupils made tables and counted reindeer in school in the same way as reindeer are counted today on the basis of everyday life in reindeer herding, where each animal is individually registered by means of a mark in a table. Counting reindeer means that the animals are sorted into categories: females, males, and calves. Each reindeer is represented by a dash in a table and the total numbers of dashes in each category are counted. Reindeer were also enumerated by the use of different terms, where reindeer herds were given names that indicate the approximate number of reindeer (see Nutti 2007). In grouse hunting, body measurements were used for the construction of traps. Hand span and the fist were the measurements used to measure the height and size of the trap. During the outdoor mathematics the pupils measured snow depth in the same way as reindeer herders by means of traditional body measurements, but the pupils were first allowed to find the best way to measure snow depth, the distance between different places, and sizes of buildings. A reindeer herder showed the pupils how he used the goartil body measurement to measure snow depth. Goartil is the distance between the tip of the thumb and index finger when stretched. The reindeer herder also told the pupils why it is important for reindeer herders to measure snow depth, and it is important because if the depth is more than 6 goartil (an adult male goartil measurement) the reindeer stop grazing.

Sámi cultural theme work can be seen as attempts to recreate Sámi cultural activity in a school context. The counting and measuring during the thematic work and the way of applying the ethnomathematical knowledge were strongly linked to their practical purpose in the original context. Although a multicultural strategy was employed, there were no intercultural aims; the activities focused on Sámi cultural themes and the Sámi culture was given a place in the school context, but without school having any influence on its content. The aim of the thematic school activities was not to facilitate interaction between the Sámi and the national school culture. The activities were therefore not intercultural according to Lahdenperä's (2008) definition of the concept, but the theme work had a decolonisation perspective, as the teachers wished to provide the pupils with an opportunity to learn Sámi traditional knowledge such as reindeer counting terms, Sámi traditional body measurements, and the way of measuring snow depth. 
Multicultural school mathematics with Sámi cultural elements

Culture-based mathematics activities in Multicultural school mathematics with Sámi cultural elements consisted of mathematical tasks and problems containing Sámi cultural content from everyday activities, such as cooking, baking, sports, reindeer herding, and fishing. Here the Sámi cultural content, concepts, and themes were added to the mathematical problems, which resembled tasks in mathematics textbooks. The mathematical problems were based on a book about a Sámi girl Sanna and pupils were asked to count points in competitions or practise multiplication by converting cooking recipes to cater for more people than stated in the recipe. Each task was connected to the story in the book. One task was linked to autumn slaughter: "Sanna helps during the slaughter by stirring the blood, which they will use to make sausage and black pudding" (translated from Nutti 2010, p. 79). The task of stirring blood is strongly linked to a Sámi learning perspective, where the children were given tasks to perform during traditional activities and the teacher was well aware that many of her pupils were familiar with this context. The task was therefore similar to a Sámi everyday activity, but it also differed from everyday life when pupils were given the task of converting a recipe: "For dinner, Sanna's mom is going to make black pudding. Sanna is going to help. Here is a recipe for black pudding:

\section{Black pudding (4 persons) \\ 2.5 cups water \\ $5 \mathrm{dl}$ reindeer blood \\ 0.5 tsp salt \\ about 12 cups flour}

Before Sanna began making the black pudding her mom told her that they would be having guests, thus there would be eight persons for dinner. What should Sanna do now? For eight persons she will need to double the recipe so that there is enough for everyone" (translated from Nutti 2010, p. 79).

Afterwards the teacher reported that it was difficult to find a suitable recipe for the task, because recipes are not used in Sámi traditional cooking. For this reason the task did not resemble everyday life, but the pupils did not notice and just solved the problem as a mathematical task. Unlike theme-based work, these culture-based mathematics activities had a school mathematical framework in which the goal of adapting the recipe was that students should calculate double quantities and not interpret the task as an everyday problem in which knowledge of food preparation could be used to arrive at the solution. Culture-based activites with mathematical tasks implied teaching mathematical problems containing Sámi cultural elements. The aim was to make it possible for Sámi pupils to recognise their everyday life and culture in the mathematical tasks, and a teacher expressed: "Every pupil recognises her/himself in something." According to Gellert and Jablonka (2009), this aim could involve the risk of some pupils misunderstanding the task by over-interpretation of the cultural content, thus carrying out the tasks on the basis of everyday-life solutions. However, in this case the teacher felt that the pupils understood that the mathematical tasks based on the Sámi book should be solved as mathematical problems.

During outdoor mathematics together with another teacher, pupils were asked to measure. The first part of the task was to measure three different distances: $1 \mathrm{~m}, 10 \mathrm{~m}$, 
and $100 \mathrm{~m}$. The aim was that students would count the number of steps in $1 \mathrm{~m}$ and then realise that they could use the number of steps in $1 \mathrm{~m}$ multiplied by 10 and 100 to obtain the number of steps in $10 \mathrm{~m}$ and $100 \mathrm{~m}$, respectively. Multiplication by the dozen was something that the pupils had recently worked with in the national mathematics textbook. The teacher told me afterwards: "When we came out they forgot about multiplication. The pupils measured $1 \mathrm{~m}, 10 \mathrm{~m}$ and it was only when they had measured $100 \mathrm{~m}$ that one of them came to me and said; that was easy, we did not need to measure" (translated from Nutti 2010, p. 75).

The second part of the task was to estimate the distance to a nearby building using the same measurement method. Pupils were expected to use steps to measure the distance, where the number of steps per metre was to be used to calculate the distance to the building. The pupils walked the distance and thereafter gave their estimations of it, but no pupil's estimation was related to the number of steps she/he had taken. However, as the pupils' estimations were fairly accurate, they could not have just guessed the distance, although apparently they did not use the steps as a method of calculation. In Sámi culture, distances are estimated by eye (see Nutti 2007) and the pupils seemed to use this method. The pupils followed the teacher's instructions and walked the distance, but the number of steps did not serve as the basis for their estimation. According to Gellert and Jablonka (2009), the pupils understood the aim of the task of converting recipes. However, they interpreted the task of pacing based on their cultural competence and misunderstood the teacher's intentions, but were allowed to solve the problem in their own way on the basis of their knowledge from everyday life. The experience of Multicultural school mathematics with a Sámi cultural content revealed that the teacher must be able mathematize Sámi cultural activities in order to try to construct mathematical tasks with Sámi cultural content and, if necessary, be able to reformulate the aim of the tasks so that students have the opportunity to use their cultural knowledge to solve them.

The social action approach

\section{Sámi intercultural education based on Sámi ontology and epistemology}

Banks's (2004) fourth and last approach is the social action approach, where pupils should become engaged in social and political issues, but there were no activities of this nature in the study.

\section{Sámi teachers' perspective on moving from problems to possibilities}

A question raised at the beginning of the action research study was: "What do you think is best, a mathematics textbook written in Sámi or Swedish?" (translated from Nutti 2010, p. 61). This made me aware of the debate regarding what language should be chosen for the mathematics textbooks in Sámi schools, because as one teacher said: "What is easier than going by the book?". Prior to Sámi culture-based mathematics activities, lack of Sámi textbooks and Sámi teaching material was the main reason teachers did not work with Sámi culture-based mathematics teaching. As in the earlier evaluation study (Skolverket 2002), mathematics teaching in Sámi schools was still on the basis of the national textbook. The teachers did not use mathematics 
textbooks in Sámi because they felt that the textbooks did not lead to Sámi culturebased mathematics teaching, as they were translated textbooks, which is in line with Pettersen's (2006) conclusion. The teachers were also negative towards Sámi textbooks because they were written in Sámi dialects spoken in the Norwegian part of Sápmi. There are different dialects in the regions and also across borders, although the Sámi languages Northern, Lule, and South Sámi are spoken in both the Norwegian and Swedish parts of Sápmi. The decision to use national instead of Sámi mathematics textbooks deprived Sámi-speaking pupils of an opportunity to learn in their own language and prevented those whose second language was Sámi from enhancing their knowledge of the language. Although the use of Sámi mathematics textbooks could perhaps strengthen the Sámi learning environment for pupils whose first or second language is Sámi (Utsi 2004), teachers felt that pupils experienced difficulties attaining the goals of the Sámi language curriculum. It was also pointed out that pupils should learn other subject area within the Sámi society (Skolverket 2011). This indicates that the Sámi language curriculum covers more than just the Sámi language and thus should indirectly influence other subjects.

Although the teachers decided to use national mathematics textbooks because the Sámi textbooks were not based on Sámi culture or written in other dialects, the teachers' decision also seemed to be due to other reasons. The main reason appeared to be the teachers' desire to prepare the pupils in "the best possible way" for further studies in the municipal compulsory school system. And "the best possible way" was, in the teachers' opinion, to teach mathematics using national teaching material. The teachers considered that the pupils would have better pre-conditions for their future studies if they used national teaching materials with the same concepts and content as they would need later in their further education. The teachers' consideration is equivalent to Pais (2011). Similar to other studies (Meaney 2001; Hirvonen 2004; Balto 2008; Johansson 2009), the present study detected a conflict between Indigenous teachers' wish to give the pupils an education equal to the teaching in the national school and culture-based teaching, that is, there was a conflict between preparing the pupils for education in the national school and providing them with specific Sámi culture-based knowledge. This conflict indicated Indigenous teachers' concern about and responsibility for the pupils' future education, and their wish to prepare the pupils in "the best possible way" for their further studies. The teachers' wish can be linked to the Sámi upbringing, where the key was for the children to become iešbirgejeaddji, independent, and to birget, manage (Balto 1997). This requires knowledge and skills, and in relation to mathematics, the pupils need to be able to handle national concepts and content in their future schooling. As one of the teachers commented: "Traditions are good, but do they help the pupils to be successful?" (translated from Nutti 2010, p. 61). Teaching based on the mathematical concepts of national culture and language is here seen to give pupils "the best" opportunity to achieve good grades in the national school and society. Therefore national textbooks seemed an appropriate choice for providing pupils with the best preconditions for coping with their future education in the majority society.

Further obstacles to a culture-based education were shortage of time, restrictions due to national syllabuses and tests, disinterested parents, limited resources, and lack 
of knowledge of Sámi culture-based mathematics teaching. But despite the use of national textbooks, the teachers saw a need to bring familiar phenomena and examples from the pupils' everyday lives and culture into mathematics teaching. The teachers wished to implement Sámi culture-based mathematics teaching, but felt that they lacked the knowledge and time to implement Sámi culture-based teaching. After the implementation of Sámi culture-based mathematics activities the teachers still faced the previously described external obstacles, but those that initially seemed to prevent them from adapting to culture-based mathematics teaching no longer stopped them from starting to implement culture-based mathematics activities. The teachers' work with Sámi culture-based mathematics lessons demonstrated their competence in dealing with the described challenges. In addition, the challenges were now viewed as opportunities. Lack of teaching materials led to the teachers working creatively in trying to implement Sámi traditional knowledge in preschools and schools in accordance with Bishop's (1988) concepts: counting, measuring, and designing. This work demanded knowledge about Sámi culture, knowledge they had themselves or gained by working together with culturally knowledgeable people outside school. Lack of teaching materials as well as the content of the national curriculum poses a challenge that forces them to be creative, making it possible to view these obstacles in a positive light. Although forced to become creative in order to implement culture-based teaching, the above-mentioned lack of teaching materials did not necessarily make them creative, as teachers can be creative irrespective of teaching materials. Had teaching materials based on Sámi culture been available, the teachers might have been able to work with further implementation work.

After Sámi culture-based mathematics activities, the teachers self-critically described the challenges they experienced, emphasising their own role and working method as an obstacle to the achievement of Sámi culture-based teaching. One preschool teacher expressed:

'Maths' was included; I tried to think about it. Sometimes I forgot, but mostly I tried to include 'maths'. We counted pieces of meat and when we sawed wood, we checked how long the wood was. I might have missed some groups because I needed to rest. Then another teacher took over, who was not focused on 'maths' (translated from Nutti 2010, p. 97).

The teacher believed that she had failed in her responsibility because she had forgotten to inform her colleague about the important mathematical aim of the work. Therefore co-operation with colleagues and discussions about the pedagogical aims of the lessons are essential. In fact pedagogical discussions and exchange of knowledge turned out to be an important part of the action research study that made culturebased activities possible. As one teacher said:

I have become more aware of Sámi culture. I have gained a new perspective on how to use traditional knowledge in teaching. The fact that I gained information during seminars changed my view on traditional knowledge. Sometimes you can be blind but now I am interested in learning more...(translated from Nutti 2010, p. 84).

The exchange of knowledge self-empowered the teachers and gave them the strength to work for change. 
The teachers' self-critical examination can be viewed in the light of Laenui's (2000) decolonisation concepts: "rediscovery," "mourning," "dreaming," "commitment," and "action." The teachers' active engagement, and visions of culture-based teaching and its implementation were central. They tried to rediscover or reinvent Sámi culture in a mathematics school context. The concept of "rediscovery" led to joy and dreams, but also to mourning for lost knowledge and made the concept of "mourning" visible. The teachers used different methods to regain Sámi traditional knowledge and to integrate it into teaching. They invited elders or persons with cultural knowledge to the school or spoke to them privately and thereafter integrated the knowledge into teaching. The increased knowledge led to awareness as well as stress, because although the teachers felt that Sámi pupils should have culture-based teaching, they were aware that they did not have enough time or knowledge to make it happen right away, thus the culture-based mathematics teaching and transformation efforts gave rise to stress.

Teachers' newly developed knowledge about the ethnomathematical research field seemed to strengthen their work with Indigenous culture-based mathematics activities. Bishop's (1988) six activities in a Sámi cultural setting in an earlier study by Nutti (2007) helped the teachers to transform mathematics teaching, although they did not manage to include all of Bishop's activities. The main reason was the lack of knowledge of mathematics, which made it easier to work with the counting and the measuring activities.

\section{Indigenous teachers' culture-based mathematics teaching in Sámi schools}

During the action research study teachers changed perspective from a problemfocused perspective to a possibility-focused cultural teaching perspective and expressed a self-empowered Indigenous teacher role, in which they started to act as agents for Indigenous school-change. Teachers experienced both possibilities and challenges in Sámi culture-based mathematics teaching. Initially they were mainly challenged by external obstacles, for example lack of textbooks, that prevented culture-based implementation, and at the beginning they felt that these obstacles were beyond their sphere of influence. After the Sámi culture-based activities, the teachers mainly described the same obstacles as previously but appeared to have changed their attitude to them; some of the obstacles posed a challenge that forced them to be creative. For example the lack of teaching materials forced the teachers to become creative in order to implement culture-based teaching.

A central factor in the teachers' work with Sámi culture-based mathematics activities was the ethnomathematics research field based on Bishop's six activities (1988). It justified their work with Sámi culture-based mathematics activities and allowed them the opportunity to change the mathematics education to a Sámi culturebased one, as well as legitimising school transformation and enabling the teachers to overcome the limitations imposed by textbooks, national curricula, and tests. The teachers began to act as potential agents of Indigenous school transformation by starting to work with Sámi culture-based mathematics activities. Each teacher was self-empowered by the work and became agents for school-change in accordance with Bedford (2009). However, the teachers started to self-critically emphasise their 
own teacher role, teaching methods, and lack of knowledge as an obstacle to the achievement of Sámi culture-based teaching. Therefore in order to support the teachers to become agents for school change, they need knowledge about Indigenous knowledge, mathematics, and mathematics education, followed by the possibility to integrate the Indigenous culture into mathematics teaching.

The teachers in Nutti's study (2010) provided examples of how mathematics teaching can be integrated into an Indigenous school context by implementing culture-based mathematics activities in preschool and school. On the basis of Banks's (2004) first three approaches: Sámi culture-based activities were carried out as: Sámi cultural thematic work with an ethnomathematical content, Multicultural school mathematics with Sámi cultural elements, and Sámi intercultural mathematics teaching. No lessons corresponded with Banks's (2004) fourth approach, the social action approach. But on the other hand, Hirvonen (2004) emphasised that to achieve that approach, Sámi schools need to be based on Sámi ontology and epistemology, which requires more than individual teachers working with the implementation of culture-based teaching and teaching content. To manage to develop culture-based mathematics teaching, teachers need further training in mathematics and mathematics teaching. Additional studies of Sámi culture-based mathematics are required to guide them in their work of designing Sámi culture-based mathematics education.

Teachers' choice not to focus on culture-based teaching was grounded in their wish to prepare the pupils in "the best possible way," which resulted in the use of national teaching curriculum, as was found in other studies (Meaney 2001; Hirvonen 2004; Balto 2008; Johansson 2009). The Indigenous teachers' wish to give the pupils an education equal to the teaching in the national school can be linked to Sámi upbringing where the key was to teach children to manage, to birget (Balto 1997). To manage requires knowledge and skills, and in relation to mathematics, the teachers felt that pupils need to be able to handle national curriculum. Therefore Indigenous teachers' active implementation of culture-based mathematics teaching also should be directed towards development of an Indigenous mathematics curriculum. A point of departure for this work is reflection on the Sámi concept of "birget" (Balto 1997) and what it implies for mathematics teaching if we aim to provide Indigenous pupils with knowledge adapted to a modern community. From this perspective, the concept does not necessarily imply a choice between mathematics based on either national mathematics or Indigenous culture, but teaching that unites national school mathematics teaching with Indigenous culture-based knowledge. However, one problem today is that Indigenous culture-based knowledge is regarded as less important than school mathematical knowledge, a dilemma that also emerged in other studies (Meaney 2001) and could perhaps be avoided, as Lipka and Adams (2004) found that culture-based mathematics teaching produced good pupil results. Pupils may be able to learn Indigenous culture-based knowledge and succeed academically.

Acknowledgments I want to express my warm thanks to the teachers at Sámi schools and Sámi School Board, and especially warm thanks to the teachers that participated in the action research study as well as the children and pupils at the preschools and schools that participated in the culture-based lessons. Also thanks to the Lulea University of Technology that was responsible for the action research study. Furthermore, I want to thank the University of Tromsø that provided academic support for this article. 


\section{References}

Alexandersson, M. (1994). Metod och medvetande. Göteborg: Acta Universitatis Gothoburgenis.

Ascher, M. (1991). Ethnomathematics. A multicultural view of mathematical ideas. Belmont, California: Chapman \& Hall/CRC.

Balto, A. (1997). Samisk barneoppdragelse i endring. Oslo: Ad Notam Gyldendal AS.

Balto, A. M. (2008). Sámi oahpaheaddjit sirdet árbevirolaš kultuvrra boahttevaš buolvvaide Dekoloniserema akšuvdnadutkamuš Ruota beale Sámis. Dieđut, 4/2008.

Banks, J. A. (2004). Multicultural education: Historical development, dimensions, and practice. In J. A. Banks (Ed.), Handbook of research on multicultural education (2nd ed., pp. 3-29). San Francisco: Jossey-Bass A Wiley Imprint.

Barton, B. (1999). Ethnomathematics and philosophy. Zentralblatt fur Didaktiker Mathematik, 31(2), 54-58.

Battiste, M. (2000). Introduction: unfolding the lessons of colonization. In M. Battiste (Ed.), Reclaiming indigenous voice and vision (pp. xvi-xxx). Vancouver, Toronto: UBC Press.

Bedford, T. (2009). Promoting Educational Equity through Teacher Empowerment: Web-assisted transformative action research a counter-hereronormative praxis, doctoral thesis. Faculty of Education, Department of Educational sciences and teacher education, University of Oulu.

Bergstrøm, G. G. (2001). Tradisjonell kunnskap og samisk modernitet: en studie av villkår for tilegnelse av tradisjonell kunnskap i en moderne samisk samfunnskontekst, master thesis. Institutt for pedagogikk, Universitetet i Tromsø.

Bishop, A. J. (1988). Mathematics education in its cultural context. Educational Studies in Mathematics, 19 (2), 179-191.

Bishop, A. J. (1991). Mathematics enculturation. A cultural perspective on mathematics education. Dordrecht: Kluwer Academic Publishers.

Calderhead, J. (1996). Stimulated recall: a method for research on teaching. British Journal of Educational Psychology, 51(2), 211-217.

D'Ambrosio, U. (1985). Ethnomathematics and its place in the history and pedagogy of mathematics. For the Learning of Mathematics, 5(1), 44-48.

D'Ambrosio, U. (2006). Ethnomathematics: link between traditions and modernity. Rotterdam: Sense Publishers.

Fyhn, A. B. (2010). Sámi culture and algebra in the curriculum. In V. Durand-Guerrier, S. Soury-Lavergne, \& F. Arzarello (Eds.), Proceedings of the sixth congress of the european society for research in mathematics education (pp. 489-498). F: Lyon: Institut National de Recherche Pédagogique.

Fyhn, A. B., Sara Eira, E. J., \& Sriraman, B. (2011). Perspectives on Sámi mathematics education. Interchange: A quarterly review of education, 42(2), 185-203.

Gellert, U., \& Jablonka, E. (2009). "I am not talking about reality" world problems and the intricacies of producing legimate text. In L. Verschaffel, B. Greer, W. van Dooren, \& S. Mukhopadhyay (Eds.), Worlds and words: Modeling verbal descriptions of situations (pp. 39-53). Rotterdam: Sense Publisher B.V.

Hirvonen, V. (2004). Sámi culture and the school. Reflections by Sámi teachers and the realization of the Sámi school. An evaluation study of reform 97. Karasjok: Cálliid Lágádus.

Johansson, G. (2009). Parental involvement in the development of a culture based school curriculum. Intercultural Education, 20(4), 311-319.

Kemmis, S., \& McTaggart, R. (1988). The action research planner (3rd ed.). Victory: Deakin University.

Kuokkanen, R. (2000). Towards an “indigenous paradigm” from a Sámi perspective. Canadian Journal of Native Studies, 20(2), 411-436.

Kuokkanen, R. (2007). Reshaping the university. Responsibility, indigenous epistemes and the logic of the gift. Vancouver, Toronto: UBC Press.

Laenui, P. [Burgess, H. F.] (2000). Process of Decolonization. In M. Battiste (Ed.), Reclaiming Indigenous Voice and Vision (pp. 50-53). Vancouver, Toronto: UBC Press.

Lahdenperä, P. (2008). Interkulturellt ledarskap - förändring i mångfald. Lund: Studentlitteratur.

Lauhamaa, P. (2004). Fra undervising til læring -organisering av læring ved samisk skole, studie av arbeidsmetoder. In V. Hirvonen (Ed.), Samisk skole i plan og praksis. Hvordan möte utfordringene $i$ O97S? Evaluering av reform 97 (pp. 34-49). Karasjok: Cálliid Lágádus.

Lipka, J. \& Adams, B. (2004). Culturally Based Math Education as a Way to Improve Alaska Native Students' Math Performance. Resource document. Appalachian Collaborative Center for Learning, Assessment and Instruction in Mathematics. http://www.uaf.edu/mcc/award-recognition-and-oth/ Culturally-Based-Math-Education-as-a-Way-to-Improve-Alaska-Native-Students-Math-Performance.pdf Accessed 2 January 2013. 
Lipka, J., Mohatt, G. V., \& the Ciulistet Group. (1998). Transforming the culture of schools. Yupik eskimo examples. Mahwah: Lawrence Erlbaum Associates.

Lipka, J., Parker Webster, J., \& Yanez, E. (2005). Introduction. Journal of American Education. Special Issue, 44(3), 1-8.

Meaney, T. (2001). An indigenous community doing mathematics curriculum development. Mathematics Education Research Journal, 13(1), 3-14.

Meaney, T., Trinick, T., \& Fairhall, U. (2012). Collaborating to meet language challenges in indigenous mathematics classrooms. Dordrecht: Springer.

Nutti, Y. J. (2007). Matematiskt tankesätt inom den samiska kulturen - Utifrån samiska slöjdares och renskötares berättelser, licentiate thesis. [Mathematical thinking within the Sámi culture - On basis of Sámi handcrafters' and Reindeer herders' stories]. Luleå University of Technology, Department of Education.

Nutti, Y. J. (2010). Ripsteg mot spetskunskap i samisk matematik-Lärares perspektiv på transforamtionsaktiviteter i samisk förskola och sameskola, doctoral thesis. [Grouse steps towards front line knowledge in Sámi mathematics - Teachers' perspective on transformations activities in Sámi preschool and Sámi school.] Luleå University of Technology, Department of Education.

Nutti, Y. J. (2012). Förändringsarbete för en kulturellt baserad samisk matematikundervisning. Tangeten, 2/ 2012, 48-52.

Ödman, P. J. (2007). Tolkning, förståelse, vetande. Hermeneutik i teori och praktik (2nd ed.). Stockholm: Norstedts Akademiska Förlag.

Pais, A. (2011). Criticisms and contradictions of ethnomathematics. Educational Studies in Mathematics, 76, 209-230. doi:10.1007/s10649-010-9289-7.

Pettersen, S. (2006). Flerkulturelle perspektiver i laerebøker og lcereplaner $i$ matematikk etter L07 og L97S - med fokus på samisk kultur og samisk skole. Oslo: Høgskolen i Oslo.

Rönnerman, K. (2000). Att växa som pedagog - Utvärdering av ett aktionsforskningsprojekt i förskolan. Report No 23/2000. Göteborgs Universitet, Institutionen för pedagogik och didaktik.

Sameskolstyrelsen (2007). Sameskolstyrelsens skolplan 2007-2010. Bilaga 21/97.

Skolverket (2002). Nationell kvalitetsgranskning av skola och barnomsorg 2001/2002. Sameskolan $i$ Jokkmokk.

Skolverket (2011). Läroplan för sameskolan,förskoleklassen och fritidshemmet 2011.

Smith, G. (2000). Protecting and respecting indigenous knowledge. In M. Battiste (Ed.), Reclaiming indigenous voice and vision (pp. 209-224). Vancouver, Toronto: UBC.

Smith, L. T. (2004). Decolonizing methodologies. Research and indigenous peoples (7th ed.). Dunedin: University of Otago Press.

Townsend, J. G., Zapata, E., Rowlands, J., Alberti, P., \& Mercado, M. (1999). Empowerment matters; understanding power. In J. G. Townsend, E. Zapata, J. Rowlands, P. Alberti, \& M. Mercado (Eds.), Women and power. Fighting patriarchies \& poverty (pp. 19-45). London: Zed Books.

Utsi, M. B. (2004). En fortelling om laeremidler... Om laeremiddelsituasjonen ved L97S-Skoler. In V. Hirvonen (Ed.), Samisk skole i plan og praksis. Hvordan möte utfordringene i O97S? Evaluering av Reform 97 (pp. 131-150). Karasjok: Cálliid Lágádus.

Vithal, R., \& Skovsmose, O. (1997). The end of innocence: a critique of 'ethnomathematics'. Educational Studies in Mathematics, 34(2), 131-158. Available from: http://www.jstor.org/stable/3482984 Accessed 2 January 2013. 